\title{
Combating Wear of ASTM A36 Steel by Surface Modification Using Thermally Sprayed Cermet Coatings
}

\author{
Vineet Shibe $^{1}$ and Vikas Chawla ${ }^{2}$ \\ ${ }^{1}$ Research Scholar, IKG Punjab Technical University, Kapurthala, Punjab 144603, India \\ ${ }^{2}$ Ferozepur College of Engineering and Technology, Ferozepur, Punjab 142052, India
}

Correspondence should be addressed to Vineet Shibe; shibevineet@gmail.com

Received 21 July 2016; Accepted 20 October 2016

Academic Editor: Katsuyuki Kida

Copyright (C) 2016 V. Shibe and V. Chawla. This is an open access article distributed under the Creative Commons Attribution License, which permits unrestricted use, distribution, and reproduction in any medium, provided the original work is properly cited.

\begin{abstract}
Thermal spray coatings can be applied economically on machine parts to enhance their requisite surface properties like wear, corrosion, erosion resistance, and so forth. Detonation gun (D-Gun) thermal spray coatings can be applied on the surface of carbon steels to improve their wear resistance. In the present study, alloy powder cermet coatings WC- $12 \%$ Co and $\mathrm{Cr}_{3} \mathrm{C}_{2}-25 \% \mathrm{NiCr}$ have been deposited on ASTM A36 steel with D-Gun thermal spray technique. Sliding wear behavior of uncoated ASTM A36 steel and D-Gun sprayed WC-12\% Co and $\mathrm{Cr}_{3} \mathrm{C}_{2}-25 \% \mathrm{NiCr}$ coatings on base material is observed on a Pin-On-Disc Wear Tester. Sliding wear performance of WC- $12 \%$ Co coating is found to be better than the $\mathrm{Cr}_{3} \mathrm{C}_{2}-25 \% \mathrm{NiCr}$ coating. Wear performance of both these cermet coatings is found to be better than uncoated ASTM A36 steel. Thermally sprayed WC- $12 \%$ Co and $\mathrm{Cr}_{3} \mathrm{C}_{2}-25 \%$ NiCr cermet coatings using D-Gun thermal spray technique is found to be very useful in improving the sliding wear resistance of ASTM A36 steel.
\end{abstract}

\section{Introduction}

Wear controls the service life of machine components. Most of the components fail due to the combination of different types or modes of wear, such as corrosion, adhesion, impact, surface fatigue, abrasion, and erosion. Wear is the removal of material from the surfaces in contact when they slide or roll relative to each other [1]. It is a very slow process, but metal removal takes place steadily and continuously [2]. Wear can be minimized or controlled by using the costly, superior wear resistant materials or by the application of surface modification techniques on the low cost existing, inferior substrate materials [3]. The service life of the machine parts depends upon their surface properties and hence should be considered in design [4]. Surface engineering deals with different techniques that can be applied to achieve desired surface characteristics [5]. Surface engineering improves the performance and service life of machine parts. Its effectiveness on the performance and service life depends upon the material of the surface, alloy, type of service conditions, and the application process used [6].
Wear and friction are responsible for many problems and costs more in a modern civilization. Engineers and designers must take these factors into account while designing and constructing different equipment [7]. The economic losses due to friction and wear related issues are about 1 to $2.5 \%$ of the gross national product [8]. The estimated costs of losses due to abrasive wear range from 1 to $4 \%$ of the gross national product of an industrialized nation [9]. So, it is important to focus on improving wear resistance of machine parts, as it impacts the economy the most.

Although wear cannot be eliminated completely, it can be minimized to some extent by using different wear prevention methodologies. Some of the methods used for the prevention of wear are [10] selection of better material, lubrication, temperature control, alignment control, environmental control, contact pressure control, preventive maintenance, and use of surface coatings. Surface coating by thermal spraying is an optimum preventive method which is mostly used in the practical field of application.

The desired technical or decorative properties can be enhanced by the application of surface coatings. A suitable 
TABLE 1: Nominal and actual percentage composition of ASTM A36 steel.

\begin{tabular}{lcccccccccccccccc}
\hline & \multicolumn{11}{c}{ Chemical composition (weight \% age) of ASTM A36 steel substrate (IS 2062) } \\
& $\% \mathrm{C}$ & $\% \mathrm{Si}$ & $\% \mathrm{Mn}$ & $\% \mathrm{P}$ & $\% \mathrm{~S}$ & $\% \mathrm{Al}$ & $\% \mathrm{Cu}$ & $\% \mathrm{Cr}$ & $\% \mathrm{Mo}$ & $\% \mathrm{Ni}$ & $\% \mathrm{~Pb}$ & $\% \mathrm{Ti}$ & $\% \mathrm{~V}$ & $\% \mathrm{~W}$ & $\% \mathrm{Fe}$ \\
\hline Nominal & 0.16 & 0.17 & 0.46 & 0.026 & 0.019 & 0.007 & 0.048 & 0.084 & 0.018 & 0.039 & 0.007 & $<0.001$ & 0.003 & $<0.001$ & 98.89 \\
Actual & 0.19 & 0.18 & 0.92 & 0.019 & 0.022 & 0.01 & 0.01 & 0.01 & 0.002 & 0.01 & - & - & 0.001 & - & 98.626 \\
\hline
\end{tabular}

coating can be applied on the surface of existing low cost inferior substrate material in the form of a superior layer of material [11]. The purpose of applying coatings to the surface of the substrate or base material is to prevent its surface from different types of wear and to improve the appearance of its surface [12].

A number of thermal spray coating techniques are available such as D-Gun, plasma spray, and high velocity oxy-fuel (HVOF) [13]. It is a group of coating techniques in which a superior material to be coated is heated and accelerated towards the base metal to form a surface coating. A large number of materials can be deposited by thermal spraying to produce surface coatings.

D-Gun thermal spraying technique finds a variety of applications like in the aircraft industries of the United States and Japan [13]. A D-Gun consists of a long barrel, a powder feeder, and a chamber in which the combustion is initiated and controlled. Gas flows are regulated and controlled with the help of control panels provided in D-Gun [14]. It includes a manipulator to hold and control the movements of the work piece. A measured mixture of oxygen and acetylene gases is fed into the barrel along with the coating powder to be deposited. The gas mixture is ignited with a spark and the combustion produces detonation waves. The detonation waves thus produced heats and accelerated the coating powder to be deposited. Some advantages of D-Gun spray coating process is increase in wear resistance by several times, dense microstructure, lower porosity, smooth surface finish, higher microhardness, lower oxidation of in-flight particles, improved wear and erosion wear resistance, and so forth.

\section{Materials and Methods}

2.1. Selection of the Substrate Material. Selection of the base material is made after consultation with Pressure and Process Boilers, Saharanpur (India). Nominal and actual chemical composition (weight \% age) of ASTM A36 steel substrate is given in Table 1.

2.2. Preparation of Test Specimens from ASTM A36 Steel Substrate Material. Small cylindrical pins of circular crosssection having a diameter of $8 \mathrm{~mm}$ and length $30 \mathrm{~mm}$ are prepared from ASTM A36 steel material. Manufacturing process such as machining or metal cutting/removal is used for manufacturing cylindrical pins. The pins are machined to required dimensions on lathe machine by using operations like simple turning, facing, and so forth. The end faces of the specimens are ground using emery papers and subsequently polished by polishing papers before the application of surface coating.
TABLE 2: Detonation spray parameters.

\begin{tabular}{lcc}
\hline & WC-12\% Co & $\mathrm{Cr}_{3} \mathrm{C}_{2}-25 \% \mathrm{NiCr}$ \\
Gases & \multicolumn{1}{c}{ Flow rate (std. liters per hour) } \\
\hline Oxygen & 2960 & 2720 \\
Acetylene & 2400 & 2320 \\
Nitrogen & 720 & 720 \\
\hline
\end{tabular}

2.3. Thermal Spray Powders for Coatings. Two types of cermet coating powders, namely, WC-12\% Co and $\mathrm{Cr}_{3} \mathrm{C}_{2}-25 \%$ $\mathrm{NiCr}$, are selected for detonation spray deposition on the ASTM A36 steel substrate specimens after the through literature review. Scanning electron microscope (SEM) images and energy-dispersive X-ray spectroscopy (EDS) patterns showing the morphologies, microstructure, and elemental composition of WC-12\% Co and $\mathrm{Cr}_{3} \mathrm{C}_{2}-25 \% \mathrm{NiCr}$ feedstock powders have been shown in Figure 1. The results obtained from EDS confirm that WC-12\% Co powder contains C, Co, and $\mathrm{W}$ elements and $\mathrm{Cr}_{3} \mathrm{C}_{2}-25 \% \mathrm{NiCr}$ powder contains $\mathrm{C}, \mathrm{Ni}$, and $\mathrm{Cr}$ elements.

2.4. Formulation of the Coating. WC- $12 \% \mathrm{Co}$ and $\mathrm{Cr}_{3} \mathrm{C}_{2}$ 25\% NiCr powders are effectively deposited on an ASTM A36 steel substrate by the D-Gun thermal spray coating technique. These coatings are deposited at SVX Powder M Surface Engineering Private Limited, Greater Noida, U.P. (India). Very hard, dense coatings with high bond strength ranging from $70 \mathrm{MPa}$ to $75 \mathrm{MPa}$ are produced by depositing WC- $12 \%$ Co and $\mathrm{Cr}_{3} \mathrm{C}_{2}-25 \% \mathrm{NiCr}$ coating powders by $\mathrm{D}-$ Gun technique on an ASTM A36 steel substrate. The average bond strength of WC- $12 \%$ Co and $\mathrm{Cr}_{3} \mathrm{C}_{2}-25 \% \mathrm{NiCr}$ coating on an ASTM A36 steel substrate is tested using the ASTM standard C633-01 at Metallizing Equipment Company Private Limited, Jodhpur, India. A total of three specimens are tested for $\mathrm{WC}-12 \% \mathrm{Co}$ and $\mathrm{Cr}_{3} \mathrm{C}_{2}-25 \% \mathrm{NiCr}$ coating and the average value of the bond strength is found to be $74 \mathrm{MPa}$ and $71 \mathrm{MPa}$, respectively. The WC-12\% Co powder is supplied by $\mathrm{H}$. C. Starck, Germany, under the product code Amperit 518.074. The powder is agglomerated and sintered having a particle size as $10-45$ microns. $\mathrm{Cr}_{3} \mathrm{C}_{2}-25 \% \mathrm{NiCr}$ powder is supplied by H. C. Starck, Germany, under the product code Amperit 588.074. The powder is agglomerated and sintered having a particle size of 10-45 microns. The parameters used for D-Gun thermal spraying for the two coatings at a spraying distance of $165 \mathrm{~mm}$ are shown in Table 2 .

The front view and top view (macrographs) of uncoated or bare test specimens, WC-12\% Co coated pins and $\mathrm{Cr}_{3} \mathrm{C}_{2}$ $25 \% \mathrm{NiCr}$ coated pins, have been shown in Figures 2(a), 2(b), and 2 (c) respectively. 


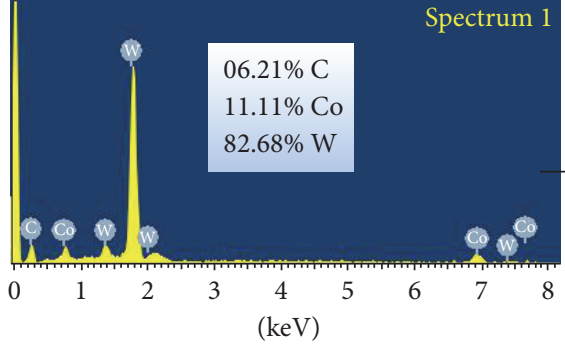

Full scale 1699 cts cursor: 0.000

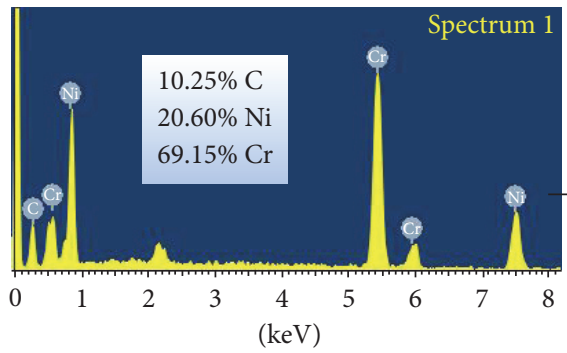

Full scale 755 cts cursor: 0.000

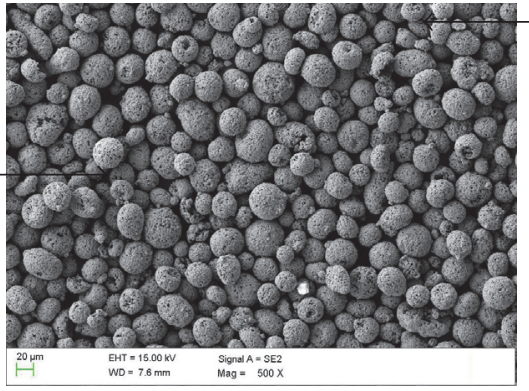

(a)

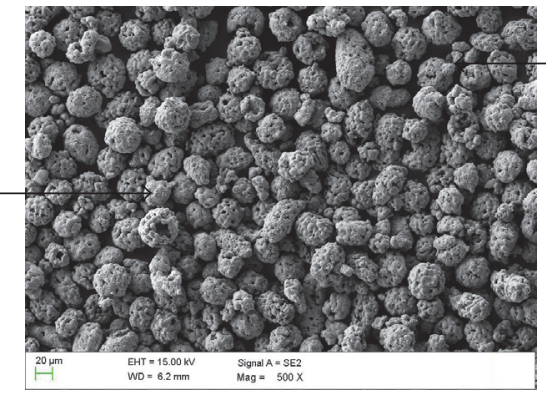

(b)

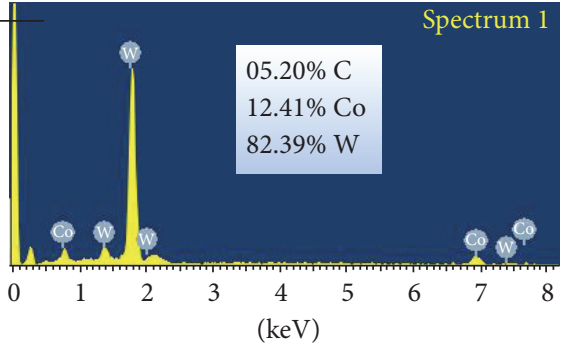

Full scale 1699 cts cursor: 0.000

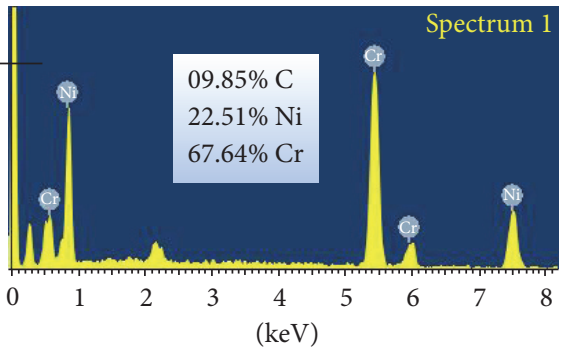

Full scale 755 cts cursor: 0.000

FIGURE 1: SEM images and EDS patterns showing the morphologies, microstructure, and elemental composition of the (a) WC-12\% Co; (b) $\mathrm{Cr}_{3} \mathrm{C}_{2}-25 \% \mathrm{NiCr}$ feedstock powders.

TABle 3: Chemical composition (weight \% age) of the EN-31 steel disc.

\begin{tabular}{cccccccc}
\hline \multicolumn{6}{c}{ Chemical composition (weight \% age) of EN31 steel } \\
$\mathrm{C}$ & $\mathrm{Si}$ & $\mathrm{Mn}$ & $\mathrm{Cr}$ & $\mathrm{Ni}$ & $\mathrm{S}$ & $\mathrm{P}$ \\
\hline $0.90-1.20$ & $0.10-0.35$ & $0.30-0.75$ & $1.00-1.60$ & 1.46 & 0.04 & 0.04 \\
\hline
\end{tabular}

2.5. Measurement of Coating Thickness. Average thickness of WC- $12 \%$ Co and $\mathrm{Cr}_{3} \mathrm{C}_{2}-25 \%$ NiCr coatings on ASTM A36 steel is measured with a thickness gauge Minitest-2000 during D-gun spraying process. Efforts are made to deposit coatings of uniform thickness of $250 \pm 10 \mu \mathrm{m}$ in all the cases of WC- $12 \%$ Co and $\mathrm{Cr}_{3} \mathrm{C}_{2}-25 \% \mathrm{NiCr}$ powders for ASTM A36 steel substrate.

2.6. Experimental Procedures. Sliding wear tests are conducted on bare and cermet coated ASTM A36 steel samples using a pin-on-disc Tester. The model of the wear and friction monitor tester used is TR-20-PHM-CHM-600 of Ducom make (Ducom Instruments Pvt. Ltd., Bangalore, India) conforming to ASTM G 99 standard. Wear tests are performed on the flat end faces of the pins at room temperature in air having a relative humidity of $51.5 \%$. During wear testing the specimen pin is held stationary against the counter face of a rotating disc at fixed track diameter. Rotating disc is made of an alloy steel (EN-31) which was case hardened (63 to 65 HRC). The composition of EN-31 steel material is given in Table 3.

2.7. Sliding Wear Studies. The specifications of the pin-ondisc tester used for wear testing include wear track diameter ranging from 10 to $100 \mathrm{~mm}$, speed ranging from 200 to
$2000 \mathrm{rpm}$, normal load ranging from 5 to $200 \mathrm{~N}$, and sliding velocity ranging from 0.5 to $10 \mathrm{~ms}^{-1}$. Both the disc and the pin are thoroughly cleaned and dried, before conducting the wear tests. The pin is loaded against the rotating disc through a dead weight loading system. The test parameters taken in the present investigation include wear track diameter $(D)$ of $80 \mathrm{~mm}$, speed of rotation of the disc $(N)$ at $477 \mathrm{rpm}$, and three different normal applied loads of $40 \mathrm{~N}, 50 \mathrm{~N}$ and $60 \mathrm{~N}$. The specimen pins are held at a fixed wear track diameter of $80 \mathrm{~mm}$ in order to have a constant sliding velocity $(v)$ of $2 \mathrm{~ms}^{-1}$ throughout the wear testing, as $v=(\pi D N / 60) \mathrm{ms}^{-1}$. Thus, the wear tests are conducted for bare and coated specimens at a constant sliding velocity of $2 \mathrm{~ms}^{-1}$ at three different normal applied loads of $40 \mathrm{~N}, 50 \mathrm{~N}$, and $60 \mathrm{~N}$. A constant linear sliding velocity of $2 \mathrm{~ms}^{-1}$ is maintained by adjusting the speed of rotation of the disc. Wear tests are conducted for a total sliding distance of $10,800 \mathrm{~m}$ for each specimen. Weight losses of all the samples are measured after $5,5,10,10,20$, and 40 minutes to find the wear loss. The weight is measured on a microbalance to an accuracy of $0.001 \mathrm{~g}$. This weight loss data is used to determine the cumulative wear rate (C.W.R). Results of C.W.R. (in Bowden) with the sliding distance $(\mathrm{m})$ are reported in the results and discussion.

\section{Results}

3.1. Microstructure of the Coatings. The Scanning electron microscope (SEM) micrographs for D-Gun sprayed WC-12\% Co coating on ASTM A36 is shown in Figure 3(a) and for $\mathrm{Cr}_{3} \mathrm{C}_{2}-25 \%$ NiCr coating on the same substrate is shown in Figure 3(b). Figure 3(a)(A) depicts the small size splats in 

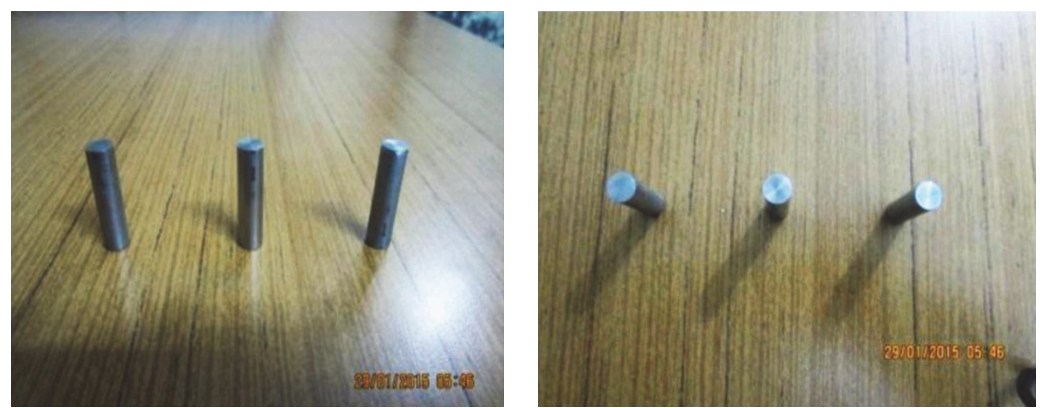

(a)
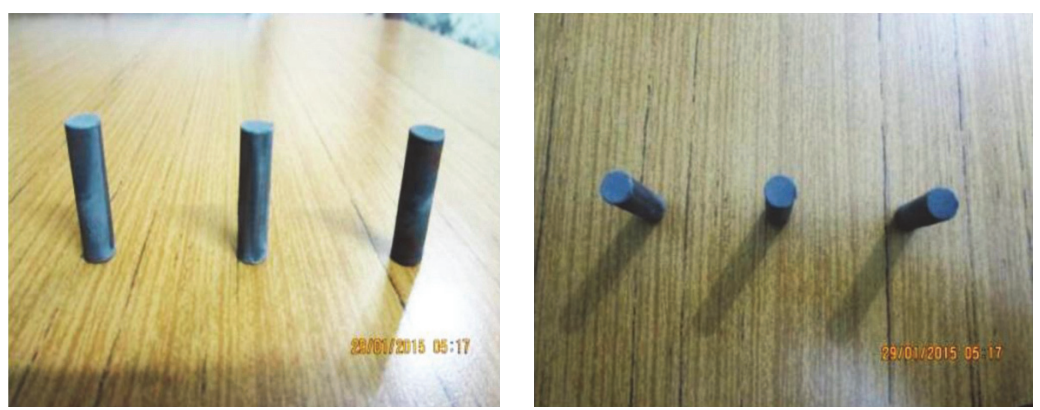

(b)
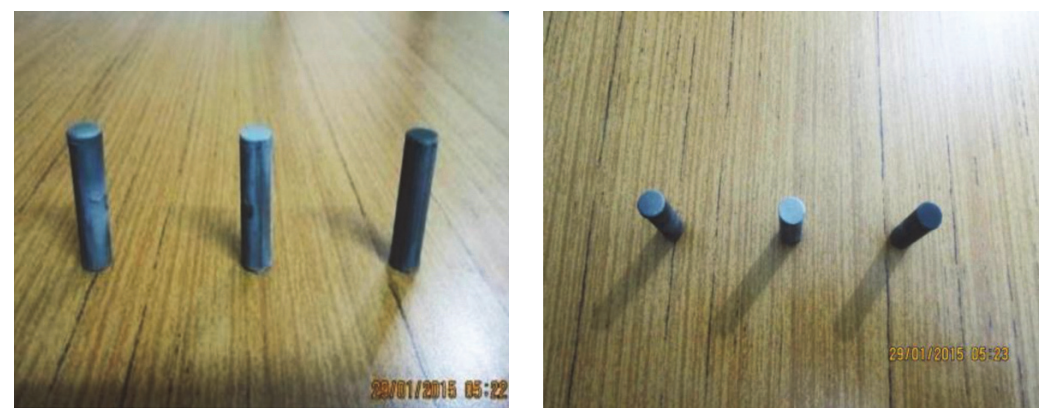

(c)

FIGURE 2: The figure shows the front view and top view (macrographs) of (a) uncoated or bare (ASTM A36) test specimens; (b) WC-12\% Co coated pins; (c) $\mathrm{Cr}_{3} \mathrm{C}_{2}-25 \% \mathrm{NiCr}$ coated pins prepared for the sliding wear testing on pin-on-disc wear tester.

case of WC-12\% Co coating whereas Figure 3(b)(A) shows the coarse splats in case of $\mathrm{Cr}_{3} \mathrm{C}_{2}-25 \% \mathrm{NiCr}$ coating. Figures 3(a)(B), 3(a)(C), 3(a)(D), 3(b)(B), 3(b)(C), and 3(b)(D) depict the SEM images of the worn samples of WC-12\% Co and $\mathrm{Cr}_{3} \mathrm{C}_{2}-25 \% \mathrm{NiCr}$ coating after the conduct of wear tests at the normal applied loads of $40 \mathrm{~N}, 50 \mathrm{~N}$, and $60 \mathrm{~N}$, respectively. It is quite clear from these SEM images of worn samples that, at higher applied load, there is more extensive loss of material.

3.2. X-Ray Diffraction (XRD) Analysis. XRD patterns for DGun sprayed WC-12\% Co on an ASTM A36 steel substrate is shown in Figure 4(a). XRD patterns for D-gun sprayed $\mathrm{Cr}_{3} \mathrm{C}_{2}-25 \%$ NiCr coating on an ASTM A36 steel substrate are shown in Figure 4(b). From the XRD patterns for D-Gun sprayed WC-12\% Co coating on ASTM A36 steel substrate, it is found that WC-12\% Co coated specimen showed the major phases of WC and the minor phases of Co.
From the XRD patterns for D-gun sprayed $\mathrm{Cr}_{3} \mathrm{C}_{2}-25 \%$ NiCr coating on ASTM A36 steel substrate, it is found that $\mathrm{Cr}_{3} \mathrm{C}_{2}-25 \% \mathrm{NiCr}$ coated specimen showed the major phases of $\mathrm{Cr}_{3} \mathrm{C}_{2}, \mathrm{Cr}_{7} \mathrm{C}_{3}$, and $\mathrm{Ni}$ which are desired phases of this coating.

3.3. Evaluation of Microhardness. The microhardness of the coatings is measured on the surface and along the crosssection. The cross-sectional analysis reading is taken with reference to the substrate-coating interface at intervals of 50micron approximate distances. Miniload 2 Microhardness Tester (Leitz, Germany) fitted with a Vicker's pyramidal diamond indenter is used for measuring the microhardness of the coatings at $200 \mathrm{~g}$ load at Central Tool Room, Ludhiana, Govt. of India Society, Ministry of Micro, Small and Medium Enterprises. The critical microhardness values of the substrate are found to be in the range $211-220 \mathrm{HV}_{0.2}$. The WC-12\% 


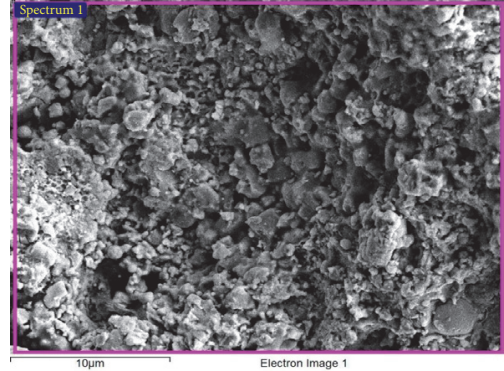

(A)

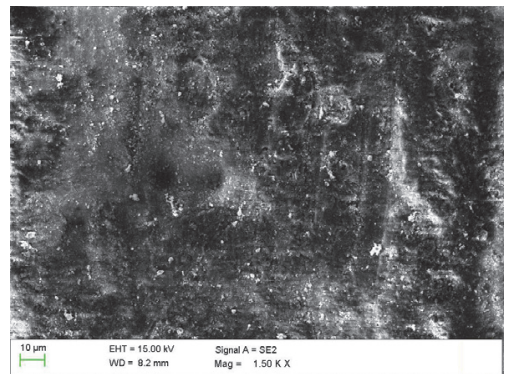

(C)

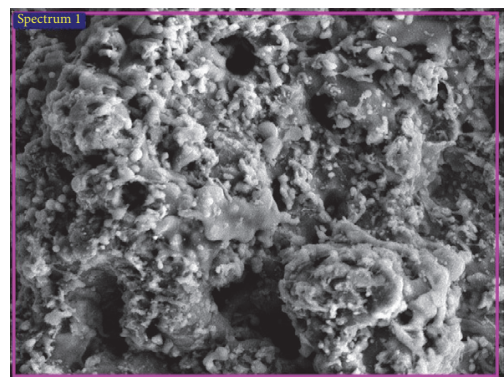

(A)

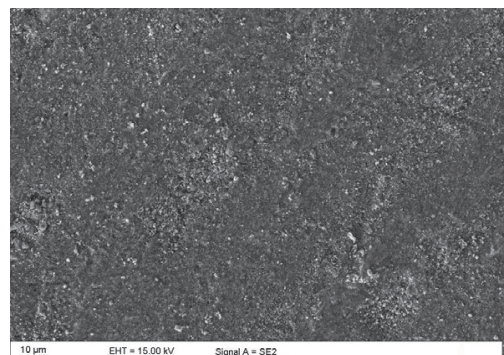

(C)

(a)

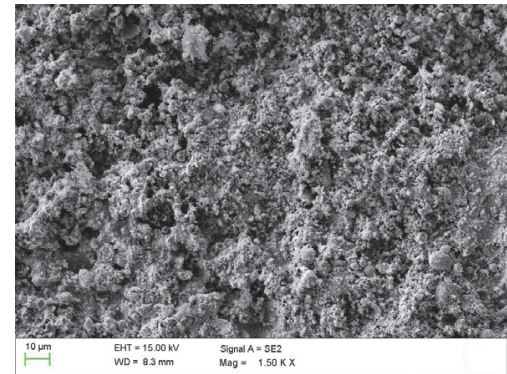

(B)

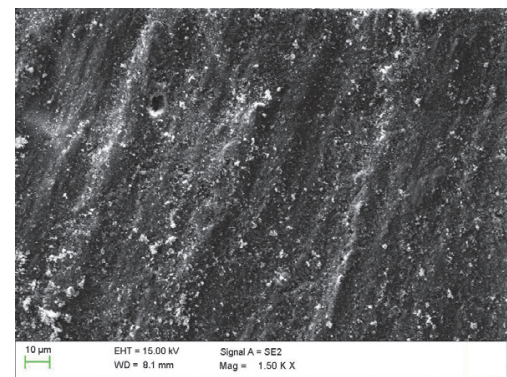

(D)

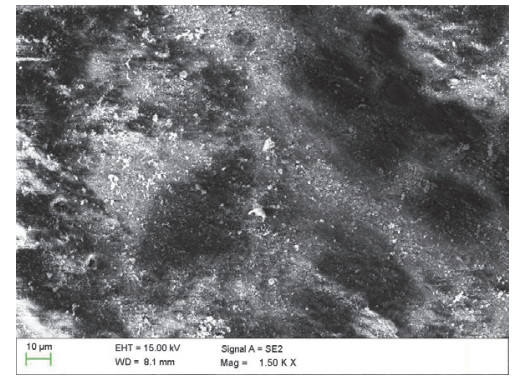

(B)

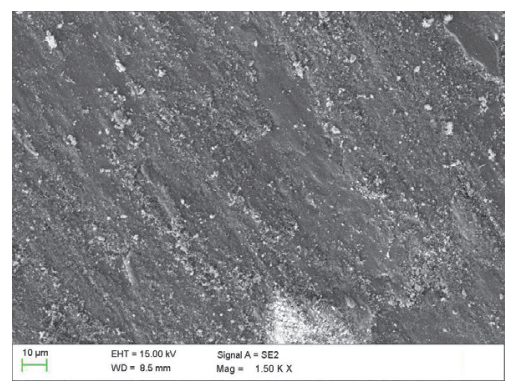

(D)

(b)

Figure 3: (a) SEM images of D-Gun sprayed WC-12\% Co coating showing: (A) Unworn surface; (B) Surface worn under a load of 40 N; (C) Surface worn under a load of $50 \mathrm{~N}$; (D) Surface worn under a load of $60 \mathrm{~N}$. (b) SEM images of D-Gun sprayed $\mathrm{Cr}_{3} \mathrm{C}_{2}-25 \% \mathrm{NiCr}$ coating showing: (A) Unworn surface; (B) Surface worn under a load of $40 \mathrm{~N}$; (C) Surface worn under a load of $50 \mathrm{~N}$; (D) Surface worn under a load of $60 \mathrm{~N}$. 


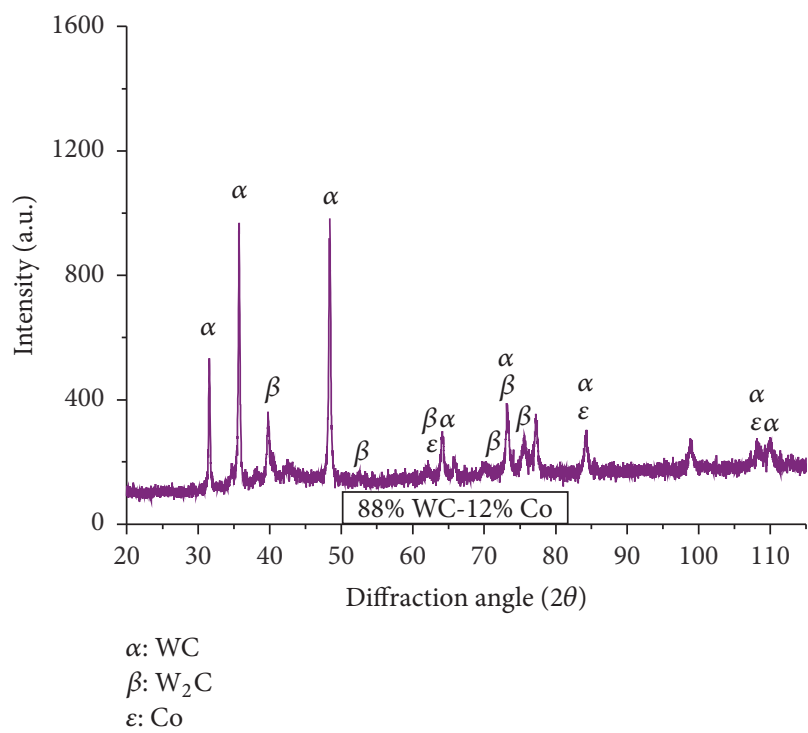

(a)

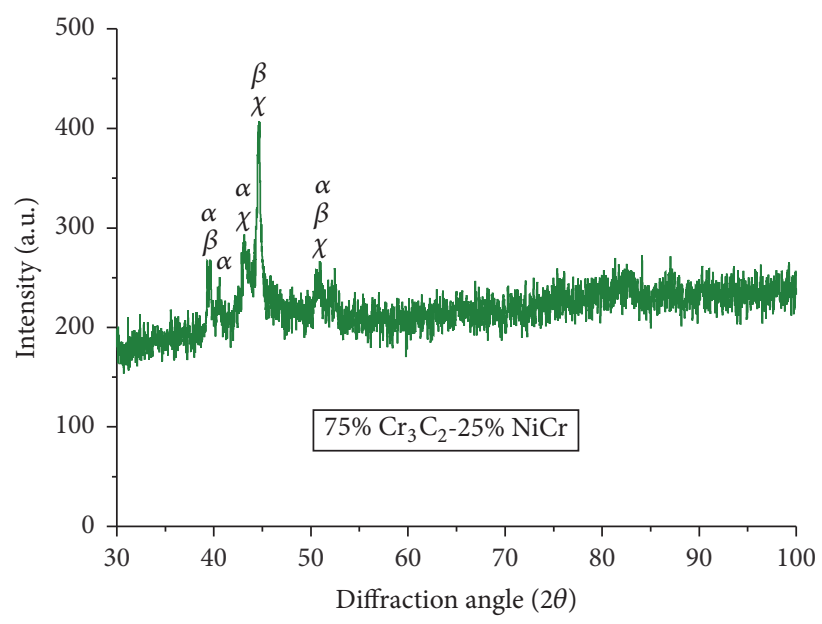

$\alpha: \mathrm{Cr}_{3} \mathrm{C}_{2}$ $\beta: \mathrm{Cr}_{7} \mathrm{C}_{3}$ $\chi: \mathrm{Ni}$

(b)

FIGURE 4: X-ray diffraction patterns of D-Gun sprayed (a) WC-12\% Co; (b) $\mathrm{Cr}_{3} \mathrm{C}_{2}-25 \% \mathrm{NiCr}$ coating on an ASTM A36 steel substrate.

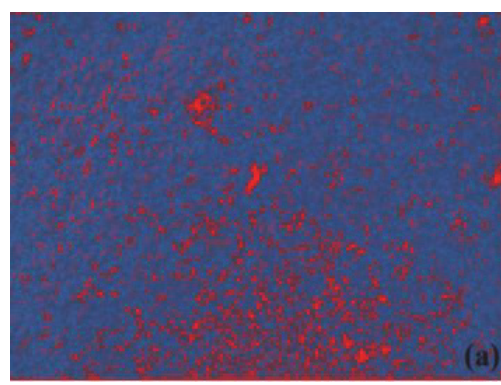

(a)

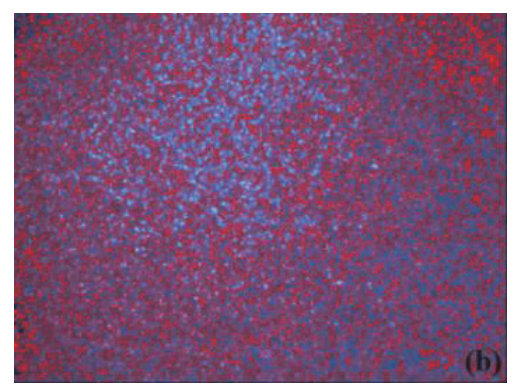

(b)

FIGURE 5: Optical images showing the porosity in D-Gun sprayed (a) WC-12\% Co; (b) $\mathrm{Cr}_{3} \mathrm{C}_{2}-25 \%$ NiCr coating on an ASTM A36 steel substrate.

Co coating has shown maximum microhardness of the order of $1178-1192 \mathrm{HV}_{0.2}$. $\mathrm{Cr}_{3} \mathrm{C}_{2}-25 \% \mathrm{NiCr}$ coating has shown microhardness in the order of $716-726 \mathrm{HV}_{0.2}$.

3.4. Measurement of Porosity. Few pores and voids appear in the D-gun sprayed coatings, as it is an intermittent process during metal spraying. The porosity measurements are made by PMP3 inverted metallurgical microscope with stereographic imaging. The magnification is selected in such a way that the coating microstructure image covers the screen and permits the resolution of the voids that provides remarkably to the total porosity area percentage. The method of choosing the suitable range of light gray contrast spots is accomplished systematically by stereographic imaging to guarantee that only voids are chosen. The analysis using an image processing software decides the pore area size in the sight range by changing over the pore areas into a background color; for example, red despite whatever is left of the microstructure remains in its actual color. The area of one element is mathematically related to the total area of the image, as the program counts the number of one-color-type pixels, for example, red, and sets that as a proportion of the total number of pixels in the image, that is, the total area. Around twenty discrete locations are chosen to prevent the overlap between two locations and decide the area percent porosity [15]. The optical images depicting the porosity in D-Gun sprayed WC$12 \% \mathrm{Co}$ and $\mathrm{Cr}_{3} \mathrm{C}_{2}-25 \% \mathrm{NiCr}$ coating on an ASTM A36 steel substrate are shown in Figures 5(a) and 5(b), respectively. The average porosity of $\mathrm{WC}-12 \% \mathrm{Co}$ and $\mathrm{Cr}_{3} \mathrm{C}_{2}-25 \% \mathrm{NiCr}$ coating is found to be $0.28776 \%$ and $0.84625 \%$, respectively, on an ASTM A36 steel substrate. Thus, the average porosity of all the as sprayed coatings is found to be less than $1.0 \%$.

3.5. Measurement of Surface Roughness $\left(R_{a}\right)$ Values. Veeco Optical Profilometer (NT 1100, USA make) is used to measure the surface roughness ( $R_{a}$ values) at IIT, Roorkee. It has the three-dimensional profiling capability with excellent precision and accuracy. The roughness is found to be in the range of 2.96-4.27 $\mu \mathrm{m}$ for WC-12\% Co coatings and 3.96-4.64 $\mu \mathrm{m}$ for $\mathrm{Cr}_{3} \mathrm{C}_{2}-25 \% \mathrm{NiCr}$, respectively. 


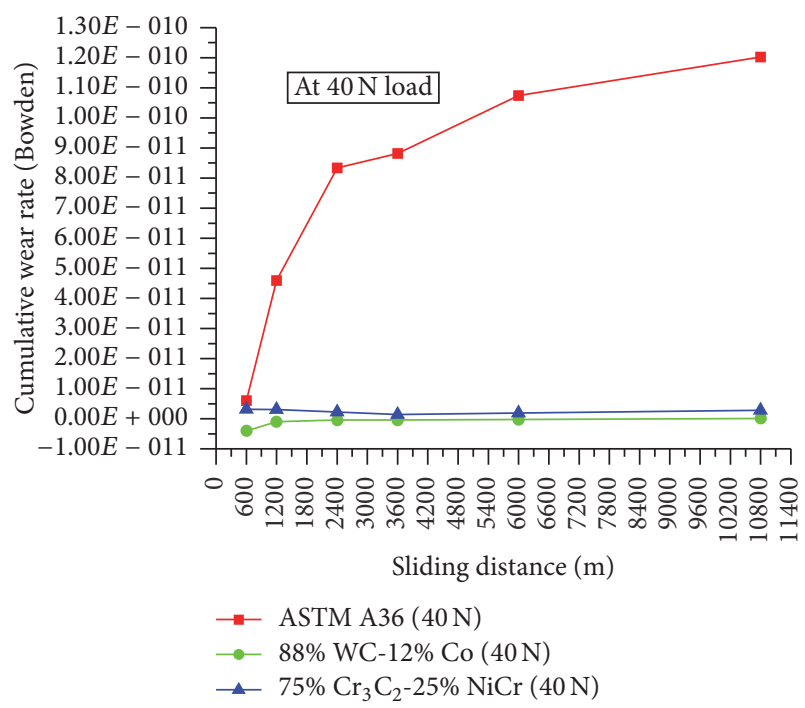

(a)

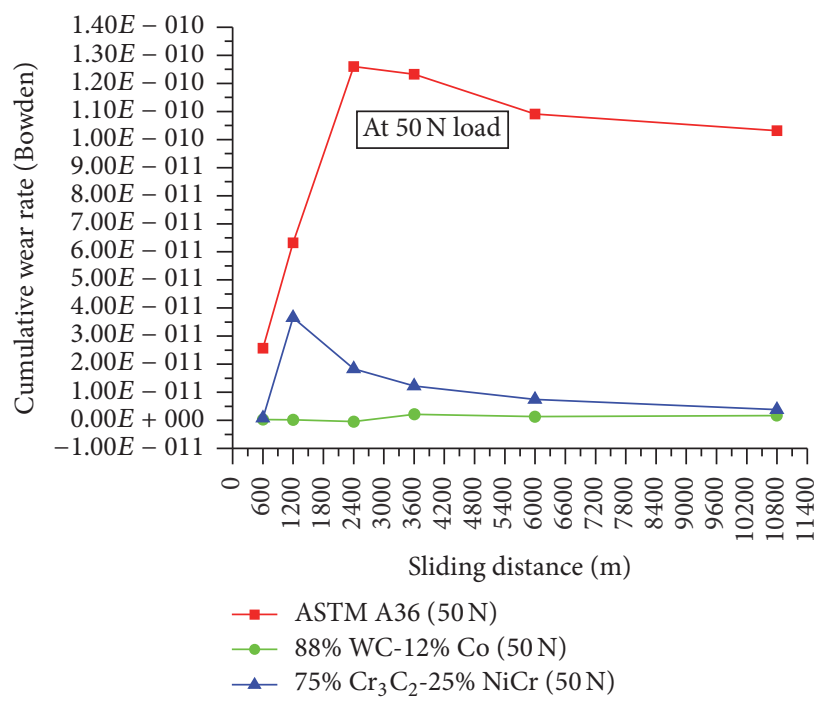

(b)

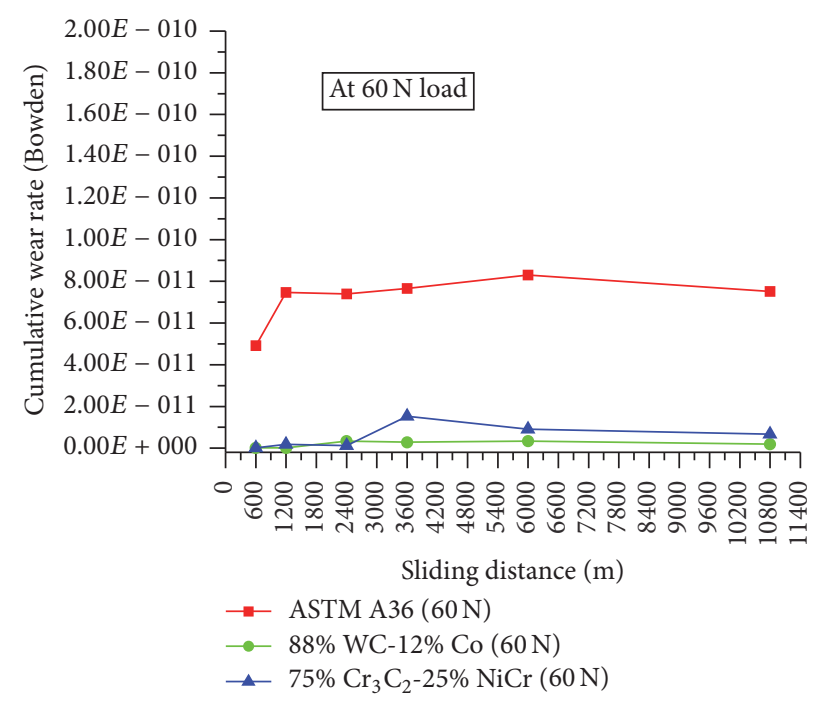

(c)

Figure 6: Variation of C.W.R. for uncoated and D-Gun spray coated ASTM A36 steel at normal applied load of (a) 40 N; (b) 50 N; (c) 60 N at sliding velocity of $2 \mathrm{~ms}^{-1}$.

3.6. Wear Behavior. Wear testing of bare as well as cermet coated specimens is conducted on a Pin-On-Disc wear tester [16] as per the standard procedure conforming to ASTM G99 standard. Variation of C.W.R. (in Bowden) with the sliding distance has been discussed in this section for the different cases under investigation. Variation of the C.W.R. with the sliding distance for bare and $\mathrm{WC}-12 \% \mathrm{Co}, \mathrm{Cr}_{3} \mathrm{C}_{2}-25 \% \mathrm{NiCr}$ coated ASTM A36 steel at a normal applied load of $40 \mathrm{~N}$, $50 \mathrm{~N}$, and $60 \mathrm{~N}$ has been plotted in Figures 6(a), 6(b), and 6(c), respectively.

It is clear from Figure 6 that the WC-12\% Co coated samples have shown considerable wear resistance at the three different applied loads of $40 \mathrm{~N}, 50 \mathrm{~N}$, and $60 \mathrm{~N}$ in comparison with $\mathrm{Cr}_{3} \mathrm{C}_{2}-25 \% \mathrm{NiCr}$ coated and bare samples.

Bar charts as shown in Figures 7(a), 7(b), and 7(c) clearly depict the C.W.R. for bare and D-Gun spray coated ASTM
A36 steel at normal applied load of $40 \mathrm{~N}, 50 \mathrm{~N}$, and $60 \mathrm{~N}$ at a sliding velocity of $2 \mathrm{~ms}^{-1}$, after a sliding distance of $10,800 \mathrm{~m}$.

These plots and bar charts clearly show that the bare ASTM steel specimen has shown much higher C.W.R as compared to cermet coated specimens at all the different applied loads of $40 \mathrm{~N}, 50 \mathrm{~N}$, and $60 \mathrm{~N}$. Therefore, it can be concluded that at different loads of $40 \mathrm{~N}, 50 \mathrm{~N}$, and $60 \mathrm{~N}$ the D-Gun sprayed WC-12\% Co coating has shown considerable wear resistance as compared to the $\mathrm{Cr}_{3} \mathrm{C}_{2}-25 \% \mathrm{NiCr}$ coated specimens and bare ASTM A36 steel.

\section{Discussion}

4.1. Microstructure of the Coatings. The WC- $12 \%$ Co coating has small size splats whereas the splats are coarse for $\mathrm{Cr}_{3} \mathrm{C}_{2}$ $25 \%$ NiCr. From the SEM images as shown in Figures 3(a)(B), 


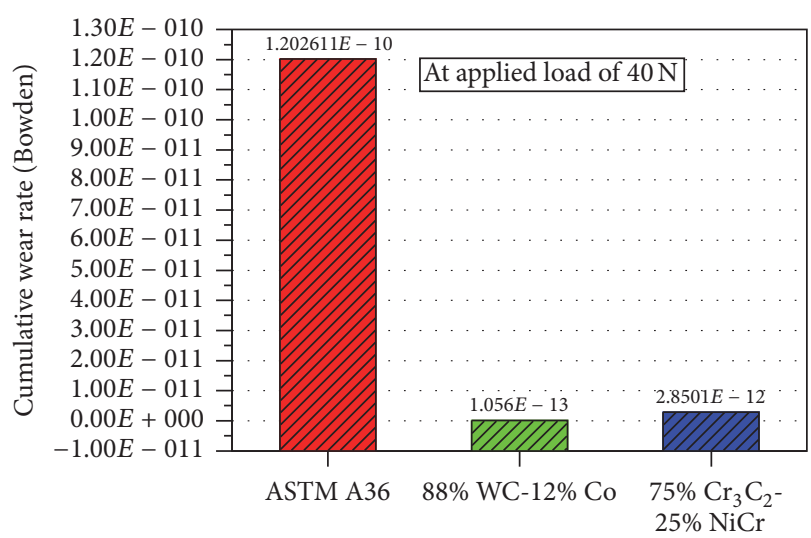

(a)

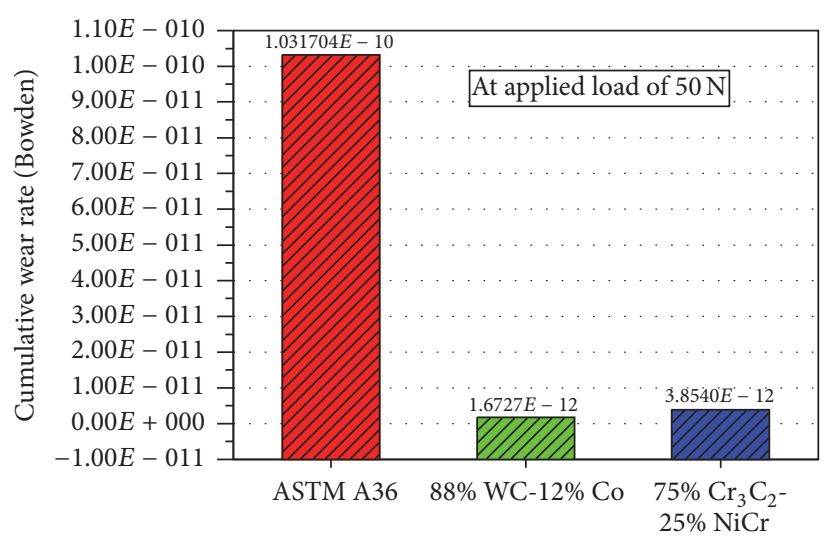

(b)

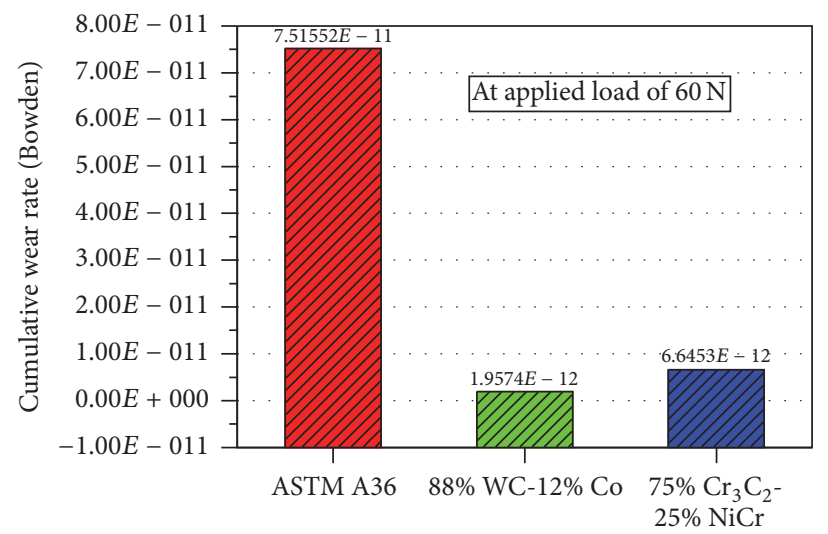

(c)

FIGURE 7: Bar chart showing C.W.R. for uncoated (bare) and D-Gun sprayed coated ASTM A36 steel at normal applied load of (a) 40 N; (b) $50 \mathrm{~N}$; (c) $60 \mathrm{~N}$ at a sliding velocity of $2 \mathrm{~ms}^{-1}$, after a sliding distance of $10,800 \mathrm{~m}$.

3(a) (C), 3(a)(D), 3(b)(B), 3(b)(C), and 3(b)(D) it is clear that, at higher applied load, there is more extensive loss of material. There is no subsurface cracking in the case of the coated specimens. WC- $12 \%$ Co coated samples were found to be more wear resistant at three different applied loads of $40 \mathrm{~N}, 50 \mathrm{~N}$, and $60 \mathrm{~N}$ than $\mathrm{Cr}_{3} \mathrm{C}_{2}-25 \% \mathrm{NiCr}$. In the present investigation, superior wear resistance of WC-12\% Co coating is found which may be due to the presence of $\mathrm{W}$ on its surface. Similar results and microstructure are obtained by Chivavibul et al. [17] for WC-Co coatings. The microstructure obtained for $\mathrm{Cr}_{3} \mathrm{C}_{2}-25 \% \mathrm{NiCr}$ coatings are similar to the findings of Kamal et al. [18].

4.2. X-Ray Diffraction (XRD) Analysis. The number of peaks corresponding to different phases of WC-12\% Co and $\mathrm{Cr}_{3} \mathrm{C}_{2}$ $25 \% \mathrm{NiCr}$ coatings on ASTM A36 material can be seen from diffraction patterns as shown in Figures 4(a) and 4(b), respectively. Theses identified phases for WC-Co coatings are in agreement with those observed by Suresh Babu et al. [19]. XRD phases identified for $\mathrm{Cr}_{3} \mathrm{C}_{2}-25 \% \mathrm{NiCr}$ coatings are in agreement with the findings of Mohanty et al. [20].

4.3. Evaluation of Microhardness. The higher microhardness values of $\mathrm{WC}-12 \% \mathrm{Co}$ and $\mathrm{Cr}_{3} \mathrm{C}_{2}-25 \% \mathrm{NiCr}$ cermet coatings may be one of the reasons of high wear resistance of these coatings, which is in agreement with those observed by Sahraoui et al. [21].

4.4. Measurement of Porosity. The lower porosity of WC-12\% $\mathrm{Co}$ and $\mathrm{Cr}_{3} \mathrm{C}_{2}-25 \% \mathrm{NiCr}$ cermet coatings may be one of the reasons of high wear resistance of these coatings, which is also supported by the findings of Sahraoui et al. [21].

4.5. Surface Roughness $\left(R_{a}\right)$ Values. Coatings are differentiated on the basis of their properties like porosity, microhardness, microstructure, surface roughness and residual stresses. The surface of the coating is rough due to the due to the presence of fully melted and partially melted particles.

4.6. Wear Behavior. From the plots showing the variation of the C.W.R. with the sliding distance for bare and WC- $12 \% \mathrm{Co}$, $\mathrm{Cr}_{3} \mathrm{C}_{2}-25 \% \mathrm{NiCr}$ coated ASTM A36 steel at a normal applied load of $40 \mathrm{~N}, 50 \mathrm{~N}$, and $60 \mathrm{~N}$, it is evident that the WC-12\% Co and $\mathrm{Cr}_{3} \mathrm{C}_{2}-25 \% \mathrm{NiCr}$ cermet coated samples have shown lower C.W.R than uncoated ASTM A36 steel samples at all these three different applied loads.

From the bar charts showing C.W.R. for uncoated and D-Gun sprayed coated ASTM A36 steel at normal applied 
load of $40 \mathrm{~N}, 50 \mathrm{~N}$, and $60 \mathrm{~N}$ at a constant sliding velocity of $2 \mathrm{~ms}^{-1}$, after a sliding distance of $10,800 \mathrm{~m}$, it is clear that the bare ASTM steel specimen has shown much higher C.W.R as compared to cermet coated specimens at all these three different applied loads. D-Gun sprayed WC-12\% Co coating has shown considerable wear resistance as compared to the $\mathrm{Cr}_{3} \mathrm{C}_{2}-25 \% \mathrm{NiCr}$ coated specimens and bare ASTM A36 steel at all these three different applied loads. Also, it is found that the C.W.R for WC-12\% Co and $\mathrm{Cr}_{3} \mathrm{C}_{2}-25 \% \mathrm{NiCr}$ cermet coated samples and bare ASTM A36 steel samples increases with an increase in the applied normal load.

D-Gun sprayed coatings are more wear resistant than bare or uncoated material which is in agreement with what was observed by Murthy et al. [22], Sundararajan et al. [23], and Wang et al. [24]. The wear rate is observed to increase with increase in applied load which is in agreement with what was observed by Qureshi and Sheikh [25]. Glaeser [26] opinioned that the wear rate is proportional to load and sliding distance during wear testing which fully supports the test results. Identical to the findings of the wear tests in the present study, enhancement of wear resistance of steel substrates is also observed after the deposition of coatings by Kulu and Phil [27]. The improvement of wear resistance after the deposition of coatings is also supported by the findings of Sahraoui et al. [21].

\section{Conclusions}

In the present investigation, the main conclusions on the basis of the results obtained are as follows:

(1) WC-12\% Co and $\mathrm{Cr}_{3} \mathrm{C}_{2}-25 \% \mathrm{NiCr}$ cermet coatings have successfully been deposited on ASTM A36 steel substrate.

(2) WC- $12 \%$ Co and $\mathrm{Cr}_{3} \mathrm{C}_{2}-25 \% \mathrm{NiCr}$ cermet coated samples have shown lower C.W.R than uncoated ASTM A36 steel samples.

(3) Enhancement in sliding wear resistance of ASTM A36 steel is observed after the deposition of WC-12\% Co and $\mathrm{Cr}_{3} \mathrm{C}_{2}-25 \% \mathrm{NiCr}$ cermet coatings.

(4) C.W.R for cermet coated specimens and uncoated specimens increases with an increase in the applied normal load.

(5) Minimum C.W.R is observed for WC-12\% Co coated specimens. WC-12\% Co is found to be the best coating to be deposited on an ASTM A36 steel substrate in the present study.

(6) Sliding wear resistance of WC-12\% Co coating is found to be better than $\mathrm{Cr}_{3} \mathrm{C}_{2}-25 \% \mathrm{NiCr}$ coating.

(7) Sliding wear resistance for all the investigated cases followed the trend as given below:

the trend is WC- $12 \%$ Co coated ASTM A36 steel $>\mathrm{Cr}_{3} \mathrm{C}_{2}-25 \% \mathrm{NiCr}$ coated ASTM A36 steel > Bare ASTM A36 steel,

therefore, out of these combinations WC- $12 \%$ CoASTM A36 coating-substrate combination is found to be the best combination.

\section{Competing Interests}

The authors declare that there is no conflict of interests regarding the publication of this paper.

\section{Acknowledgments}

The authors wish to thank the Pressure and Process Boilers, Saharanpur, India, for providing the substrate material; SVX Powder M Surface Engineering Private Limited, Greater Noida, U.P., India, for providing the facility of the detonation gun (D-Gun) thermal spray coating; Ducom Instruments Pvt. Ltd., Bangalore, India, for providing the wear and friction monitor tester (Model: TR-20-PHM-CHM-600) for the conduct of wear testing; IIT, Roorkee, India, for extending the facility of SEM/EDS and XRD analysis during this work. The authors are highly grateful to the officials, staff, and supervisor appointed by the IKG Punjab Technical University, Kapurthala, for their guidance and support.

\section{References}

[1] B. Bhushan and B. K. Gupta, Handbook of Tribology: Material Coating and Surface Treatments, McGraw-Hill, New York, NY, USA, 1991.

[2] J. F. Archard, Wear Control Handbook: Wear Theory and Mechanisms, Edited by M. B. Peterson and W. O. Winer, ASME, New York, NY, USA, 1980.

[3] H. Singh, M. S. Grewal, H. S. Sekhon, and R. G. Rao, "Sliding wear performance of high-velocity-oxy-fuel spray $\mathrm{Al}_{2} \mathrm{O}_{3} / \mathrm{TiO}_{2}$ and $\mathrm{Cr}_{2} \mathrm{O}_{3}$ coatings," Proceedings of the Institution of Mechanical Engineers, Part J: Journal of Engineering Tribology, vol. 222, no. 4, pp. 601-610, 2008.

[4] J. Stokes, Thermal Spray Process: Theory and Application of the High-Velocity-Oxy-Fuel (HVOF), Dublin City University, Dublin, Ireland, 2008.

[5] J. Halling, Introduction: Recent Development in Surface Coating and Modification Processes, Mechanical Engineering Publications Limited, London, UK, 1985.

[6] R. Arulmani and S. Pandey, "Surfacing applications: a review," in Proceedings of the National Workshop on Welding Technology, Department of Mechanical Engineering, S.L.I.E.T., Longowal, India, 2003.

[7] H. P. Jost, “Tribology-origin and future," Wear, vol. 136, no. 1, pp. 1-17, 1990.

[8] Z. G. Karl-Heinz, Microstructure and Wear of Materials, Tribology Series 10, Elsevier, Tokyo, Japan, 1987.

[9] A. Vencl, "Abrasive wear resistance of the iron and WC-based hardfaced coatings evaluated with scratch test method," in Proceedings of the 13th International Conference on Tribology (SerbiaTrib '13), Kragujevac, Serbia, 2013.

[10] S. K. Srivastava, Tribology in Industries, S. Chand and Company Limited, New Delhi, India, 2001.

[11] B. Q. Wang and S. W. Lee, "Elevated temperature erosion of several thermal-sprayed coatings under the simulated erosion conditions of in-bed tubes in a fluidized bed combustor," Wear, vol. 203-204, pp. 580-587, 1997.

[12] J. Stokes, Theory and Application of HVOF Thermal Spray Process, Dublin City University, Dublin, Ireland, 2003. 
[13] R. C. Tucker Jr., Handbook of Deposition Technologies for Film and Coatings: Advanced Thermal Spray Deposition Technologies, Edited by R. F. Bunshah, Noyes, Park Ridge, Ill, USA, 2nd edition, 1994.

[14] K. Rao, D. A. Somerville, and D. A. Lee, "Properties and characterization of coating made using jet kote thermal spray technique," in Proceedings of the 11th International Conference on Thermal Spray (Thermal Spray '86), Welding Institute of Canada, Montreal, Canada, September 1986.

[15] N. Kumar, G. Prashar, and R. K. Dhawan, "To check the feasibility of $\mathrm{Cr}_{2} \mathrm{O}_{3}$ coating on boiler steel tubes simulated coal fired boiler conditions to prevent the erosion," International Journal on Emerging Technologies, vol. 3, no. 1, pp. 126-129, 2012.

[16] Test Method for Wear Testing with a Pin-on-Disk Apparatus, "American Society for Testing and Materials International Standards," ASTM Standard G99, ASTM, 2003.

[17] P. Chivavibul, M. Watanabe, S. Kuroda, and K. Shinoda, "Effects of carbide size and Co content on the microstructure and mechanical properties of HVOF-sprayed WC-Co coatings," Surface and Coatings Technology, vol. 202, no. 3, pp. 509-521, 2007.

[18] S. Kamal, R. Jayaganthan, S. Prakash, and S. Kumar, "Hot corrosion behavior of detonation gun sprayed $\mathrm{Cr}_{3} \mathrm{C}_{2}-\mathrm{NiCr}$ coatings on $\mathrm{Ni}$ and $\mathrm{Fe}$-based superalloys in $\mathrm{Na}_{2} \mathrm{SO}_{4}-60 \% \mathrm{~V}_{2} \mathrm{O}_{5}$ environment at $900 \circ$ C, Journal of Alloys and Compounds, vol. 463, no. 1-2, pp. 358-372, 2008.

[19] P. Suresh Babu, B. Basu, and G. Sundararajan, "Processingstructure-property correlation and decarburization phenomenon in detonation sprayed WC-12Co coatings," Acta Materialia, vol. 56, no. 18, pp. 5012-5026, 2008.

[20] M. Mohanty, R. W. Smith, M. De Bonte, J. P. Celis, and E. Lugscheider, "Sliding wear behavior of thermally sprayed 75/25 $\mathrm{Cr}_{3} \mathrm{C}_{2} / \mathrm{NiCr}$ wear resistant coatings," Wear, vol. 198, no. 1-2, pp. 251-266, 1996.

[21] T. Sahraoui, N.-E. Fenineche, G. Montavon, and C. Coddet, "Structure and wear behaviour of $\mathrm{HVOF}$ sprayed $\mathrm{Cr}_{3} \mathrm{C}_{2}-\mathrm{NiCr}$ and WC-Co coatings," Materials and Design, vol. 24, no. 5, pp. 309-313, 2003.

[22] J. K. N. Murthy, D. S. Rao, and B. Venkataraman, "Effect of grinding on the erosion behaviour of a WC-Co-Cr coating deposited by HVOF and detonation gun spray processes," Wear, vol. 249, no. 7, pp. 592-600, 2001.

[23] G. Sundararajan, D. Sen, and G. Sivakumar, “The tribological behaviour of detonation sprayed coatings: the importance of coating process parameters," Wear, vol. 258 , no. 1-4, pp. 377391, 2005.

[24] J. Wang, B. Sun, Q. Guo, M. Nishio, and H. Ogawa, "Wear resistance of a $\mathrm{Cr}_{3} \mathrm{C}_{2}-\mathrm{NiCr}$ detonation spray coating," Journal of Thermal Spray Technology, vol. 11, no. 2, pp. 261-265, 2002.

[25] F. S. Qureshi and A. K. Sheikh, "A probabilistic characterization of adhesive wear in metals," IEEE Transactions on Reliability, vol. 46, no. 1, pp. 38-44, 1997.

[26] W. A. Glaeser, "Friction and wear," IEEE Transactions on Parts, Hybrids, and Packaging, vol. 7, no. 2, pp. 99-105, 1971.

[27] P. Kulu and T. Phil, "Selection criteria for wear resistant powder coatings under extreme erosive wear conditions," Journal of Thermal Spray Technology, vol. 11, no. 4, pp. 517-522, 2002. 

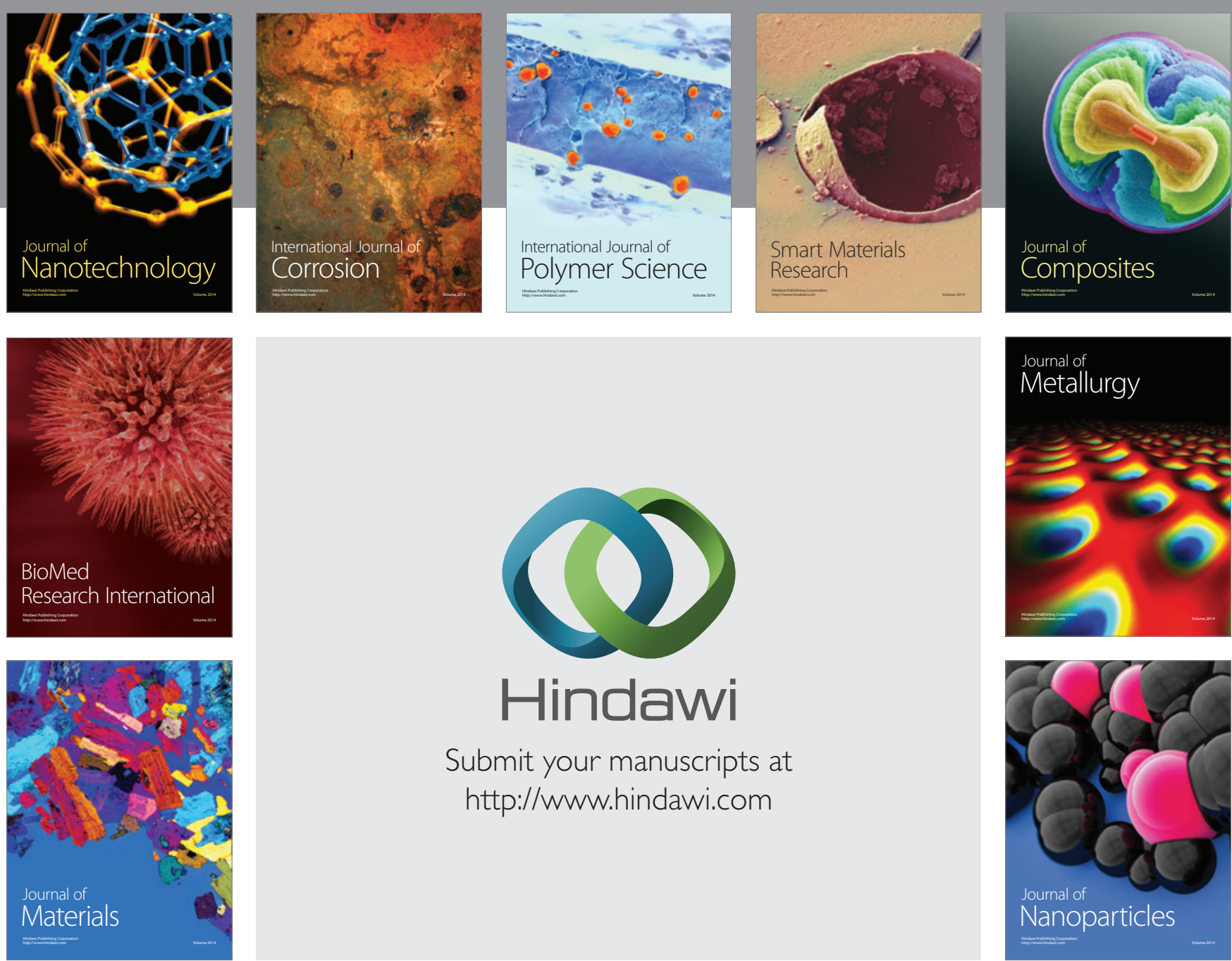

\section{Hindawi}

Submit your manuscripts at

http://www.hindawi.com

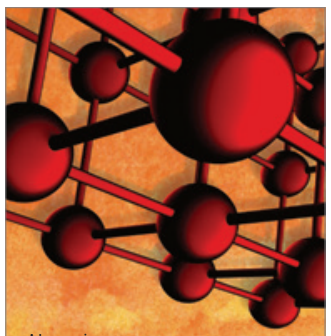

Materials Science and Engineering
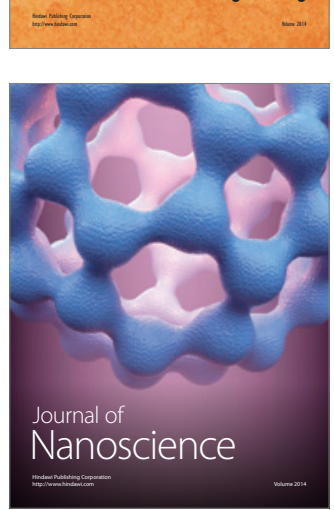
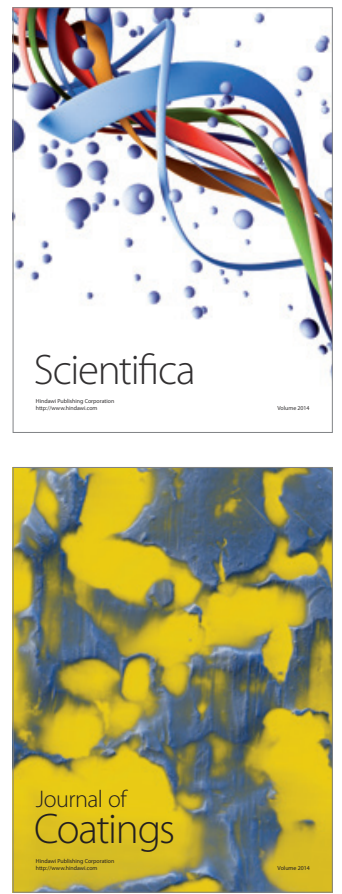
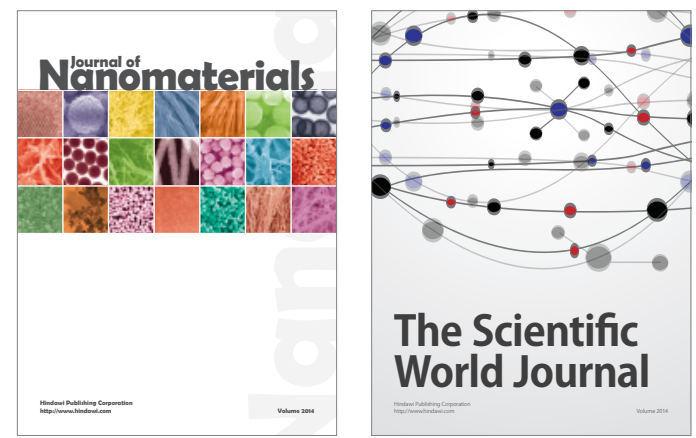

The Scientific World Journal
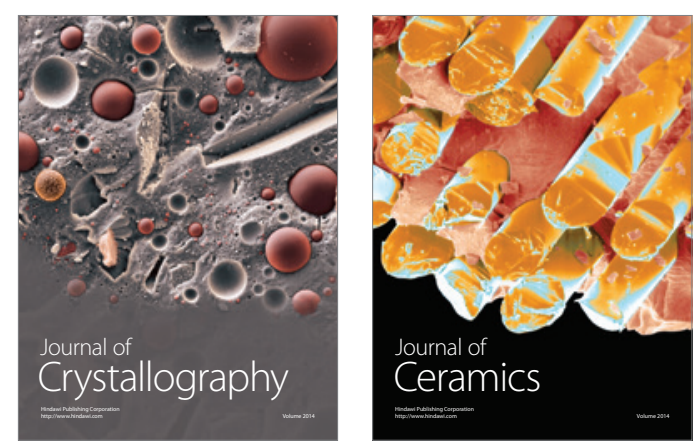
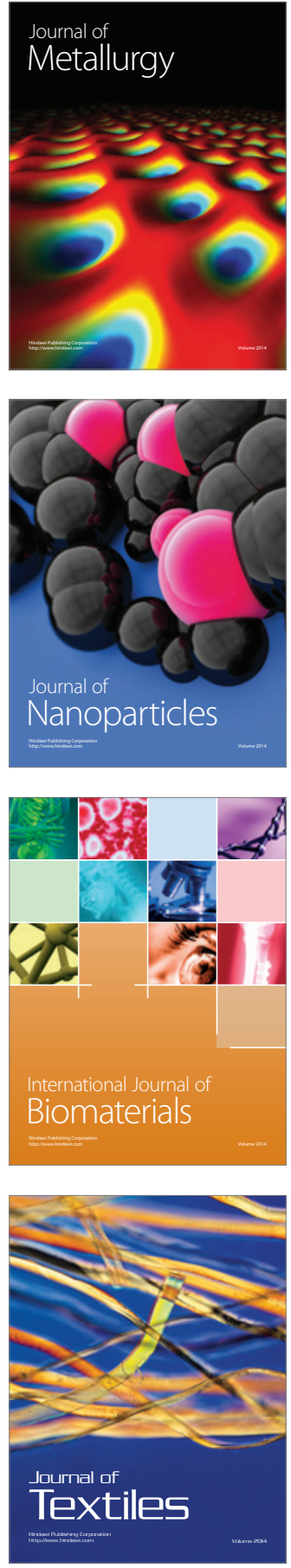